$1-1-2014$

\title{
A Socio-Marketing Analysis Of The Concept Of Cute And Its Consumer Culture Implications
}

\author{
Elad Granot \\ Cleveland State University, e.granot@csuohio.edu \\ Thomas Brashear Alejandro \\ University of Massachusetts - Amherst \\ La Toya M. Russell \\ Cleveland State University
}

Follow this and additional works at: https://engagedscholarship.csuohio.edu/bus_facpub

Part of the Marketing Commons

How does access to this work benefit you? Let us know!

Publisher's Statement

Elad Granot, Thomas B. Alejandro, \& La Toya M. Russell, A Socio-Marketing Analysis of the Concept of Cute and its Consumer Culture Implications. Journal of Consumer Culture $(14,1) \mathrm{pp}$. 66-87. Copyright @ 2014 by The Authors. Reprinted by permission of SAGE Publications, Inc.

\section{Original Published Citation}

Granot, E., Alejandro, T.B., \& Russell, L.M. (2014). A socio-marketing analysis of the concept of cute and its consumer culture implications. Journal of Consumer Culture, 14(1), 66-87. doi: 10.1177/

1469540513485274

This Article is brought to you for free and open access by the Monte Ahuja College of Business at EngagedScholarship@CSU. It has been accepted for inclusion in Business Faculty Publications by an authorized administrator of EngagedScholarship@CSU. For more information, please contact library.es@csuohio.edu. 


\title{
A socio-marketing analysis of the concept of cute and its consumer culture implications
}

\section{Elad Granot}

Cleveland State University, USA

\section{Thomas Brashear Alejandro}

University of Massachusetts Amherst, USA

\section{La Toya M. Russell}

Cleveland State University, USA

\begin{abstract}
Cute has become the favored language of (the predominantly female) popular consumer culture. This paper examines the roots of "cute" and its evolution with reference to its relevance to marketers. We follow the cultural appropriation of Japan's "Kawaii" by the Western "cute", and introduce a social, marketing-oriented description and analysis of the concept. We present its socio-cultural, experiential, symbolic, and ideological relevance to consumption in general, and to consumer culture theory in particular. This examination steers clear of scientific generalizations prevalent in consumer behavior research and aims, instead, to illuminate the cultural dimensions of the consumption cycle, and allow a better understanding of what it is like to form social attachment and loyalty in the context of cute consumption and consumer culture theory. Especially interesting questions arise regarding the trans-social acculturating elements of cute, as well as the apparent mainstreaming (cultural appropriation) of the cute Asian subculture into the dominant Western consumer and material cultures.
\end{abstract}

\section{Keywords}

Consumer, consumer culture, cute, marketing, socio-marketing, consumer culture theory 


\section{Prologue}

While working on a research paper exploring female consumers' brand-driven retail decision making (Granot et al., 2010), we interviewed female participants in a series of multiple, in-depth conversations. As we were going through the laborious process of qualitative data analysis, we initially overlooked one word that was mentioned repeatedly by all of our participants, and very often at that. It was the word was "cute". For example, participants said:

I really only go to Filene's if I see a really cute pair of Tommy Hilfiger undies.

I have this really cute BCBG handbag that I absolutely adore, it looks like a doctor's bag - it's really cute.

I don't know, there is something appealing about that store. When you walk by I always go in - I think because there is a lot of pink. They always have a nice display up front, and I usually notice the colors and for whatever reason they just fit really well, they usually have very cute styles, a nice selection - from a little bit more risky to a little bit more conservative, which I think is nice.

We almost missed it because when the initial research process began, the authors were male, and tended to use the word when referring to a baby, or a puppy. Our participants, however, used the word to describe products, brands, people, stores, and even regarded it as a state of being. When we completed that research paper, we began looking into the concept of "cute". This paper constitutes an analysis of the socio-cultural meaning of the concept of cute.

\section{Introduction}

The pursuit of being cool is a major driver of global consumer culture and it has become a principal source of status, mainly, but not exclusively, among teenagers (Belk et al., 2008). However, this may not be the case and teenagers may not be the principle source of cool status - cool teenagers might grow up to be cool adults. Brooks (2000) discusses how consumers who grew up with bohemian ideals now have to adjust their lives in order to not sell out while enjoying their comfortable life styles. He calls these consumers "Bobos" (bohemian bourgeois).

Cool, as Nancarrow et al. (2002) point out, is "essentially a male phenomenon", and women who wish to be cool appear not to wear cosmetics and make little concession to the "ideology of femininity" (McRobbie, 1991). Cool-seeking women conform to Thornton's (1995) criteria of preferring the masculine or gender-free aspects of style over the feminine. In fact, as some writers have argued, gender-free, unisex, and androgynous are ideological misnomers that privilege the male at the expense of the female (see, for example, Butler, 1990). In keeping with the disregard that culture generally shows for the 'feminine' (the long-running critique of Mass 
Culture as Woman, as described by Huyssen, 1986), cool tends towards the masculine. When women engage in what Martin et al. (2006) label as "HyperMasculine Subcultures", cute is mentioned, but only as an adjective to describe a boy one of the participants held on to in the back of a motorcycle.

Cool culture began in early 20th-century movies and books (Cross, 2004a). Boys were the first to consume these media, which challenged many of the adult conventions. The parental ideology of the time prompted parents to indulge their children's desires, but such indulgence could transform cute children into spoiled children. In addition, children themselves, overwhelmed by the saccharine nature of cuteness, often developed a style that was not cute. Cross (2004a) calls the alternative style they developed "the cool." Instead of providing boys with a moral life compass, cool culture projected a world with little parental command, empowered children, and where "escapism rather than aspiration was celebrated" (Cross, 2004a: 14 ). The resulting allure of the cool, independent way of life of modern American children is undeniable to this day. Belk et al.'s (2008) "Cool masculinity" seems to be confirmed in studies focusing on female consumers, and as Innes (1999) points out, "femininity and masculinity are defined as opposites in our culture" (p.15). If cool is, indeed, masculine, could cute be its feminine cultural counterpart?

Although the concept of cool has been substantially researched, the academic literature offers no significant effort to describe and understand the concept of cute. A number of researchers have brought up the term, with no effort to follow-up on its meaning and significance. Schroeder (2006) explores the commodification of art and describes contemporary paintings depicting "beams of sunlight, and cute country church steeples" (p.94). Brown (2002), discussing the same issue, mentions "cutesy aesthetics." Both authors offer no elaboration, discussion, definition, theoretical development, or operationalization of the concept. Shelton and Okleshen Peters (2006) cite one of their participants who describes reactions to her Winnie the Pooh tattoo as "oh, how cute." They, too, make no effort to explore the meaning of the term. Wilson et al. (2006) examined Asian consumer reactions to advertisements. Their participants talked about "cute voices," and say "MTV just seems cute." No follow-up questions are reported. Additional mentions of the term as a construct, attribute, factor, or descriptor without explanation, definition, operationalization, or any other effort to make meaning of it, appear in Beggan and Allison (2001), Cross (2002), Langmeyer and Shank (1994), Martens (2008), Moon (2000), Murray (2002), Ritson and Elliott (1999), Roux and Korchia (2006), Ruth et al. (1999), Thompson et al. (1990), and Wallendorf and Arnould (1991).

Harris (2000) suggests that cuteness is widespread in consumer culture, from cherubic figures "patting their peepers on Charmin toilet paper to teddy bears frozen mid-embrace, the stubs of their pawless arms groping for hugs."

Newitz (2002a) takes a critical tone, writing that "Something cute is happening to America...Teenage girls are mobbing the Sanrio store for the latest Hello Kitty hair bands... Lipsticks are pink and sparkly; blouses are festooned with lace; fluffy stuffed animals serve as fashion accents." Within their natural setting of their 
consumeristic landscape, such sentimental products of the modern sensibility are commonplace. Cuteness is not described as an aesthetic in the ordinary sense of the word, and is not necessarily physically appealing or attractive. However, most marketing images of cute are exactly that. Sometimes, products and brands become cute not necessarily because of a quality they have but a quality they lack, a certain neediness and inability to stand alone, a vulnerability consumers find touching. Because of this quality, cuteness has become central in the consumer culture and marketplace in that marketers have learned that consumers will adopt products that create an aura of neediness, like "the silent desperation of a lost puppy dog clamoring to be befriended - namely, to be bought" (Harris, 2000).

The main drive of consumer culture theory (CCT) research addresses issues that are germane to social scientific, managerial, and public policy constituencies (Arnould and Thompson, 2005). As such, this paper utilizes CCT as a methodological foundation for an exploration of a dominant phenomenon in contemporary consumer markets: cute. We believe it is appropriate to explore the complexity of cute because it is organized around a core set of theoretical questions related to the relationships among consumers' personal and collective identities; the cultures created and embodied in the lived worlds of consumers; their underlying experiences, processes and structures; and the nature and dynamics of the sociological categories through and across which these consumer culture dynamics are enacted and inflected. In accordance with consumer culture research, we draw from an interdisciplinary body of theory to introduce a novel foundation for a theoretical framework that can illuminate the socio-cultural dynamics that drive the cute consumption cycle and to advance a theoretical conversation around CCT's four interrelated research domains.

In this paper we focus on the origins of cute and Kawaii cute and provide a glimpse into its movement from its Japanese roots and Asian-Pacific origins into American and Western mainstream consumer audiences. We also look at the subjectivity of the cute phenomenon in contemporary consumer culture through media such as advertising, marketing, and entertainment - just to name a few. Within the last 30 years cute has evolved from a Japanese cultural phenomenon into the ubiquitous chant of almost every (female) teenager: "that's cute." Historically, most youth cultures and subcultures are led by men and considered masculinist (Brake, 1985 ) with women as auxiliaries. The gender-related nature of youth culture is not new. Nearly all originally Western youth cultures in the post-war period, such as mods, rockers, new romantics, techno, punk and hip hop, and above all, cool, have been dominated by young men with young women playing a more passive side-kick role. The much greater original involvement of men than women in other youth cultures to date has attracted little specific notice, perhaps for the simple and valid reason that the greater active involvement of young men had seemed to be normal or natural, given the general structure of modern societies. Quite the opposite is true in Japan, where women led the charge in developing cute culture. As a word it might seem to have become almost meaningless; as a concept it has considerable power, whether we regard it as what Raymond Williams called "the structure of 
feeling" of contemporary popular culture or as one of the dominant ideologies of consumer capitalism (Williams, 1965).

We therefore chose to move to a more mid-range level of analysis of this intriguing issue, still in its theoretical infancy, that seemingly "concerns the moral constitution of consumption and the nature of moral dilemmas and challenges that the commercialization of everyday life, including its most intimate moments, pose for consumers" (Arnould and Thompson, 2005). On a more practical level, we seek to answer Cross's (2002) call to "take more seriously the content and form...especially appeals to the cute and cool, giving these terms more precise definition, and identifying age, gender, and other differences in their manifestations."

This paper provides the backdrop to the genesis and evolution of cute and its cultural appropriation by Western consumers, cultures, and marketers. This is followed by a comparative study between the Asian and Western conceptualizations of cute. In particular, the Japanese notion of cute originates from "babyness" and is intrinsically female, while the Western notion of cute appears less gendered and not restricted to human characteristics. We conclude with a discussion of the consumer culture theoretical implications, as well as conclusions and future research recommendations.

\section{The birthplace of cute: Japan's Kawaii and its Asian-Pacific spinoffs}

In part because of its global media, pop culture, and consumer corporate dominance, the Asia-Pacific region, especially Japan, is considered as the key source of global cute. The Asahi Shinbun newspaper ran a story on "Japanese soft power" (Sugawa, 2000) and its spread around the world. According to Joseph Nye's (2006) thesis, Japan's influence is spreading less via the hard power of military and economy and diplomacy - but rather thanks to cuteness, or the power to attract. Allison (2003) discusses the phenomenon of Pokémon both in Japan and the USA and in ways that help revise the role of cuteness as a Japanese form of global commodity in the context of Japan's changing role on the global economy. Taking Pokémon as a symbol of "cuteness" (kawairashisa), she acknowledges its complex meaning for consumers/both Japanese and American. Pointing to both the history of kawairashisa in Japan as a site for the "imaginary" and its link to traditional Japanese culture, as well as its commodification in the 1970s with the likes of Hello Kitty, Allison (2003) suggests that "in the millennial play product(s) Japan is selling and using to sell itself -/on the popular marketplace of global kids' culture" (pp.382-383).

Cute culture was not founded by business. Rather, it started as youth culture amongst Japanese teenagers, especially young women (Kinsella, 1995). The casual observer in Japan can witness the hegemony of Kawaii or Kawaii-mono (cute things). Two examples are street-corner police boxes that take the shape of gingerbread houses, (Figure 1) and Nippon Airways jumbo jets (Figure 2) are splashed 
with giant yellow Pokémon. Although some criticize the societal infantilization that Kawaii consumer culture represents - some even blame it for creating a generation of youth unable to face reality - no one denies that cute sells (Garger, 2007).

"Cuteness" in Japan was originally a phenomenon started by youth but soon appropriated by industry. The cute lent personality to objects such that consumers could have relationships with their commodities that they might lack with other people in a society pervaded by alienation. In Japan, the popular sense of "cute" was closely associated with "pitiful." Cute was not restrained to the young (although childishness characterized much of cute), but could be evoked by anyone that appeared weak, helpless, or funny. Therefore, when young Japanese teens (especially girls) tried to be cute, they did so by hiding their strengths and appearing weak and dependent (much in the same way that American males, specifically African-American males (Robinson-English, 2006), tend to hide intelligence and feign stupidity in an effort to approximate "cool"). Goffman (1979) used print advertising and photographs to illustrate how women are shown in childlike poses while men are not. Goffman also discusses gender display and states "...ritually speaking, females are equivalent to subordinate males and both are equivalent to children" (p.5).

While cute is associated with childlike innocence, a naive spontaneity unaffected by adult restraints, ironically, Kawaii cute is consumer-oriented, contrived, cultivated, artificial, bought and sold. Thus, as Cross (2004a) explains: "most young

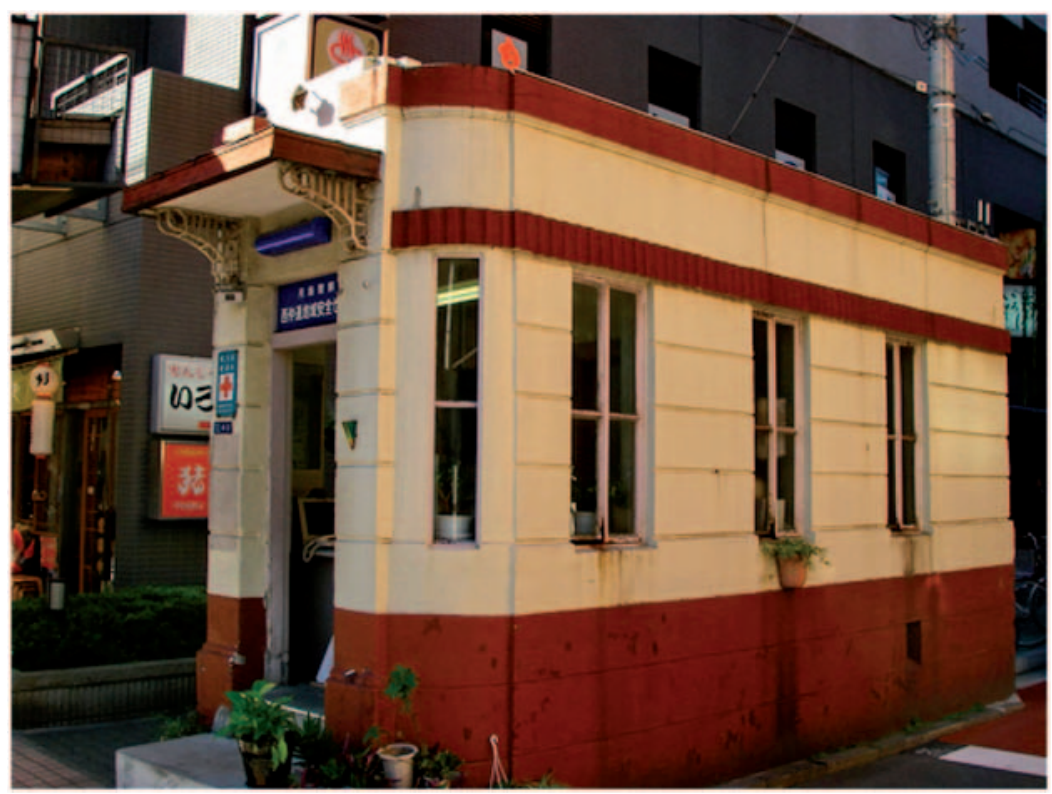

Figure I. A police gingerbread house Koban (box). Available at: http://farm4.static.flickr.com/ 3042/30753906I5_I4fb3852ea.jpg (accessed II January 2008). 
people thought that cute behavior came to them naturally, despite the markedly unnatural mannerisms and gestures that defined cute - (pigeon toes, bow-leggedness)." The cute aesthetic played a significant role at the outset of the Japanese popular consumer culture. The term "Kawaii" (cute) style was never a part of the culture until teenage girls introduced a form of handwriting written in a childlike fashion to communicate with one another, which became popular in the mid 1970s. Companies and the mass media capitalized on the cute handwriting fad in an attempt to boost domestic consumer demand. Since then, marketing the cute aspect of youth culture has been a lucrative business. As a result, the high profile of the Japanese popular culture at home and spreading overseas, attests to the enormous corporate success of aggressive marketing and promotion efforts over the years.

An example of Kawaii is Hello Kitty. Sanrio, the creator of Hello Kitty, understands cute as a marketing proposition. In 1971, it began producing cute stationery, stuffed animals, cartoon toiletries, bags, and other accessories targeting young consumers. A cute cartoon character has frequently been used on products with slogans written in silly English to communicate the perception of lighthearted fun. In promoting Hello Kitty with its tie-ins of 15,000 products, Sanrio Corp. reaps in approximately US\$3 billion annually (Lee, 2005).

The effects of the "cute" in Japanese society have become a consumer cultural phenomenon - seen in fashionable clothes and accessories, childish behavior and attitude among young women, adulation of idol singers and talents (teenagers), and

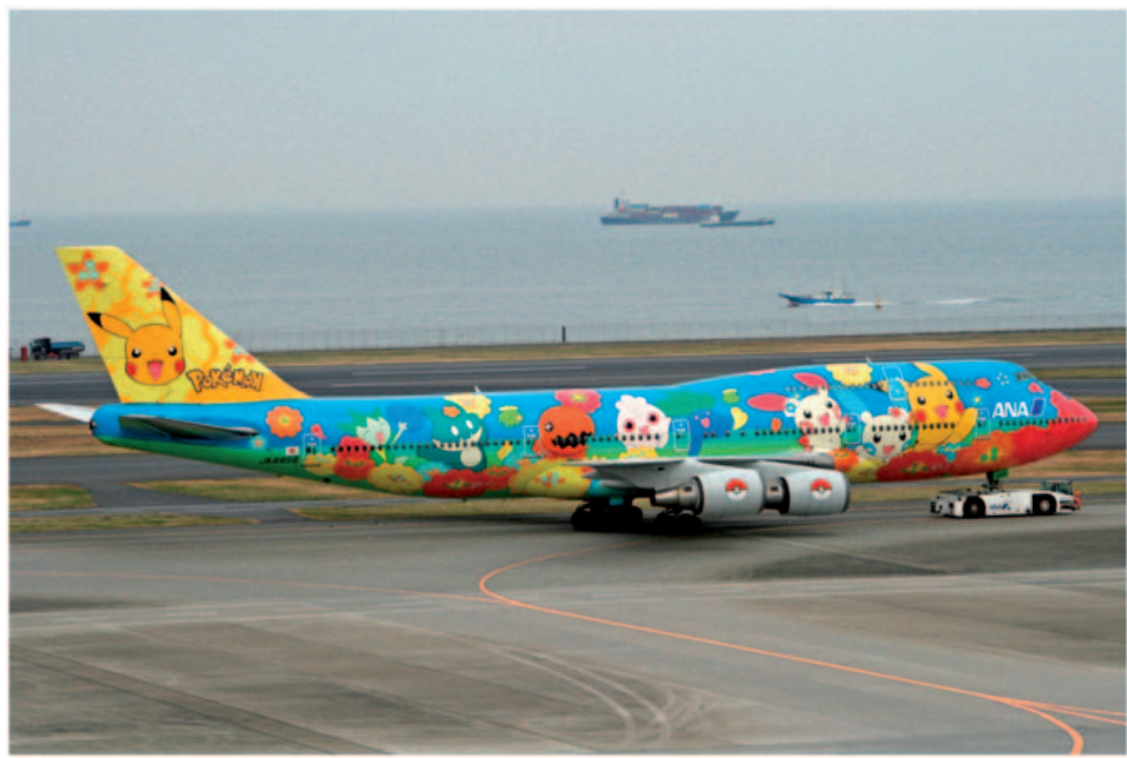

Figure 2. Nippon Airlines Pokémon jetliner. Available at: http://upload.wikimedia.org/wikipedia/commons/a/a5/All_Nippon_Airways_Pokemon_Jet_JA8956.jpg (accessed II January 2008). 
transitory lifestyles of young consumers. Japanese firms, services, and even banks, have long been using animated characters in their marketing communications. In Japanese society, as the young spend more time with computers, they tend to be isolated, fueling loneliness and the desire for making friends. Thus, they take part in the cute trend as a way to be accepted in society. Kato (2002) discusses cute "mascots" as it relates Japanese obsession. The author states that wearing cute mascots allows for an escape from alienation and the wearer can identify with a particular group. If you show a funny and cute mascot, people may assume you are an easy-going person.

The convenience of email and the popularity of cell phones actually bring the Japanese more than ever in touch with one another, contrary to the perception of isolation (Hjorth, 2005). The cell phone segment is one of the most prominent manifestations of cute culture in consumer goods markets. In the Asia-Pacific region, a form of cell phone customization that seems to dominate among the fashions is that of the cute (Kawaii) (Hjorth, 2005). This "cuteness" is overtly informed by a Japanese "cuteness" (kawairashisa); whether in the form of actual Japanese products or in hybrid, indigenized forms such as the Korean (yet Japanese-sounding) cute character series entitled Toyamoya. This form of customization occurs both outside (cute characters hanging or dressing up the device) and inside (as screen savers or net "friends") the phone and is used to signify both practices of individualization (McVeigh, 2003) and social capital (Bourdieu and Nice, 1984; Ling, 2004).

In order to discuss the multiple cartographies of kawairashisa as it migrates Asia and beyond, one must reinvestigate the role of Japan in this region. While there has been some work into the theorizing of kawairashisa in Japan (Kinsella, 1995; McVeigh, 2000), the only studies that address the "cute" outside of Japan do so in terms of critiquing of the so-called Japanization of the region, as in Yu-Fen Ko's study of the Hello Kitty "invasion" in Taiwan (Ko, 2003).

Kawaii draws on old traditions. Long before Japan turned out the smallest and cutest electronic gizmos, it was the birthplace of the charming haiku. Netsuke, dainty miniature sculptures that functioned as fasteners for purses during the Edo period (1603-1867), could be as adorable as any Pokémon. Evidence of Japanese women's custom of appearing cute is the geisha. However, today's Kawaii springs from the country's modernization. Rising incomes and burgeoning media and advertising during the postwar boom ushered in a consumer culture that fuels fads and the whims of the young. Kawaii is a by-product of affluence, and correlates with the rise of a very strong consumer society in the 1970s and the media culture that sustained it.

Bremner (2006) describes the everyday visual landscape of Tokyo, the ad banners on the subway, storefronts signs, digital display screens, and various forms of mass media such as manga (Japanese comics) and fashion magazines, as just "oozing with cute stuff." Cute is not just a marketing gimmick. It is embedded in the culture and manifests itself in social and gender roles, particularly those of young Japanese women. Moreover, cute is not just a fashion statement-pink 


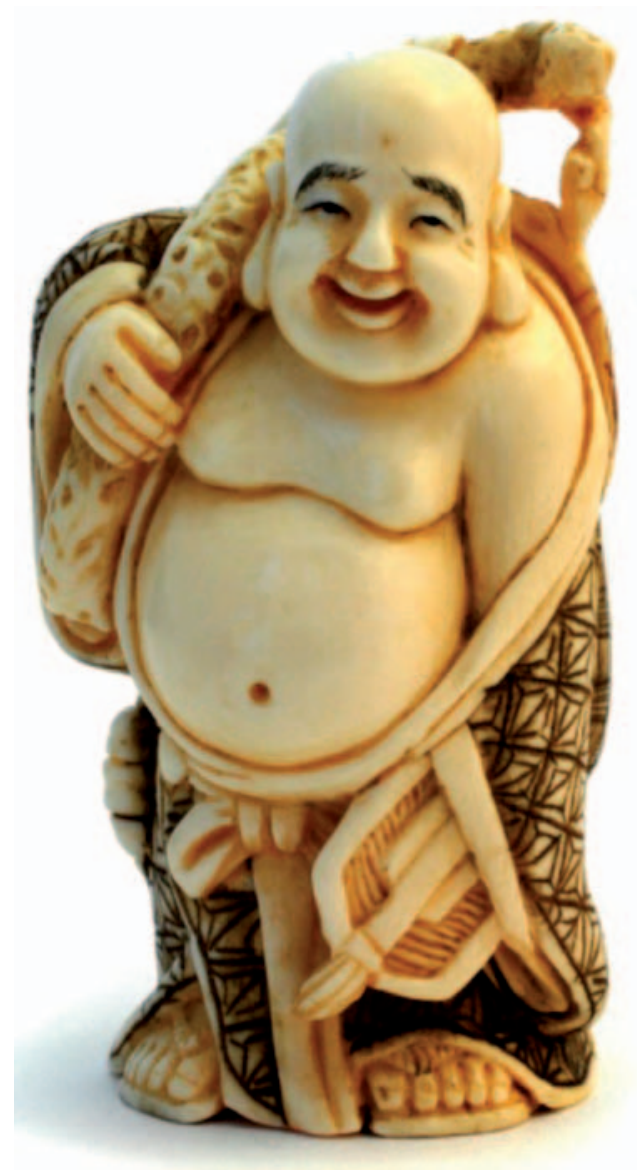

Figure 3. Buddha Netsuke. Available at: http://upload.wikimedia.org/wikipedia/commons/3/39/ Mammoth_ivory_netsuke_buddha.JPG (accessed II January 2008).

lipstick, butterfly hair bands, and pastel colors - it is also a mode of behavior. Cute girls often act silly, affect squeaky voices, pout and stomp their feet when they are angry. It seems to be a cultural statement.

As Lee (2005) explains, the world has been captivated by the Japanese popular culture, especially the Asian youths, as a rising new generation of middle-class Asian consumers who could easily identify with Japan's values and lifestyles. Whether attracted to Hello Kitty, teen idols, trendy fashion, or fun, snazzy, quality products, the young Asians described the charm of the Japanese youth culture in one word- "cute!"

\section{The evolutional aspects of cute}

Angier (2006) states that scientists who study the evolution of visual signaling have identified a wide and still-expanding assortment of features and behaviors that 
make something look cute: bright forward-facing eyes set low on a big round face, a pair of big round ears, floppy limbs and a side-to-side, teeter-totter gait, among many others. Cute characteristics include both physical and personality traits. Physical characteristics include rounded face or head, large eyes, tiny nose and a small size in general, while personality traits include fragility, helplessness, or playfulness, so essentially, what you are looking at are sets of characteristics of an infant. Angier (2006) also explains that according to evolutionary psychology, this is what draws people to cuteness. Cuteness is distinct from beauty, emphasizing rounded over sculptured, soft over refined, clumsy over quick. Cute cues are those that indicate extreme youth, vulnerability, harmlessness, and need, and attending to them closely makes good Darwinian sense.

The greater the number of cute cues that an animal or object happens to possess, or the more exaggerated the signals may be, the louder and more italicized are the squeals provoked. Beauty attracts admiration and demands a pedestal; cuteness attracts affection and demands a lap. Beauty is rare and brutal, despoiled by a single pimple. Cuteness is commonplace and generous, content on occasion to co segregate with homeliness. According to Stokes (2007), human preference for cute or attractive animals over less charismatic creatures will increasingly affect which species survive and which ones perish in the years ahead. That is because we often base our attraction on superficial criteria, such as color and "cuteness." Humans tend to prefer animals that possess cuddly traits such as fur, button-noses, or proportionally large eyes, but cuteness is not the determining factor in animals of very similar species.

\section{The social significance of cute}

However, what exactly defines "cute"- the image that melts our hearts and makes its consumers both desire and desirable? Cross (2004b), writes that the ideology of "wondrous innocence" shaped adult expectations about how children should look and act. In the late 19th and early 20th century, Americans became smitten with the "cute" child who showed innocent desire. Because adults regarded children as uncorrupted, they considered their longings to be pure and good rather than base and materialistic. In the 20th century, this ideology has justified and encouraged children's consumerism.

For women, affection for cute things means more than reflecting their preferences, as it is a reflection of a deep longing to the time when they were girlish and young (Granot et al., 2010). On a more materialistic level and based on our research, we infer that all of the cute products described in this paper attest to a rapidly expanding desire for cute, cuddly, reassuring consumption experiences.

Newitz (2002) provides an effective, although strongly biased, introduction to the topic: "Why is everything so damn cute? The fluffy-bunny regime is getting ugly." (p.21). She reminds us of the understandable appeal of cute 
creatures: they appeal to the child in each of us, and like comfort food, we seek out cute things when we need reassurance during stress, just as nutritionists inform us that we seek sugar and carbohydrates.

\section{Manifestations of cute in consumer markets: Fanshi Guzzu - the fancy goods industry}

The fundamental ingredients of a fancy good are that it is small, pastel, round, soft, loveable, not traditional Japanese style but a foreign, in particular European or American, style, dreamy, frilly, and fluffy (Kinsella, 1995). The author also says that most fancy goods are also decorated with cartoon characters. The essential anatomy of a cute cartoon character is small, soft, infantile, mammalian, round, without bodily appendages (arms), without bodily orifices (mouths), non-sexual, mute, insecure, helpless, or bewildered. While Kinsella (1995) describes the anatomy of a cute cartoon character as non-sexual, we draw the readers' attention to the fact that one person's non-sexual is clearly another's sexual.

\section{Cute fashion}

Cute fashion in Japan is more than merely cuddling cute things: it is all about 'becoming' the cute object itself by acting infantile (Kinsella, 1995). The demanding ideal of cute fashion generates a built-in orientation towards the consumption of goods that could transform a young person to look, and feel, something like a child. Cute fashion was, therefore, a kind of rebellion or refusal to cooperate with established social values and realities. It was a demure, indolent little rebellion rather than a conscious, aggressive, and sexually provocative rebellion of the sort that has been typical of cool-questing Western youth cultures (Belk et al., 2008). Rather than acting sexually provocative to emphasize their maturity and independence, Japanese youth acted pre-sexual and vulnerable in order emphasize their immaturity and inability to carry out social responsibilities (Kinsella, 1995). Either way, the result was the same; teachers in the West were as infuriated by cocky male pupils acting cool, as Japanese teachers were infuriated with uncooperative female pupils writing cute and acting infantile.

Cute clothing is designed to make the wearer appear childlike and demure. Original cute clothes were simple white, pink, and pastel shades for women and bright and rainbow-colored for men. The clothes were often fluffy and frilly with puffed sleeves and lots of ribbons - a style known as 'fancy' - or alternatively were cut slightly small or tight and came decorated with cartoon characters and slogans. For example, young Japanese consumers, especially women, purchased cute accessories and filled their rooms, cars, work desks, and purses with sweet paraphernalia as a way of surrounding themselves by cuteness to the point where they felt transformed and could enter this cute-only world themselves (Kinsella, 1995). 


\section{Childhood romance, adulthood, and individualism in Japan}

Our research so far has confirmed Kinsella's (1995) claims that cute style is concerned with acting childish in an effort to partake of some of the childhood's simplicity, happiness, and emotional warmth. It is important to point out that underpinning cute style are the "neo-romantic notions of childhood as an entirely separate, pure sphere of human life" (Kinsella, 1995: 22). In fact, it is generally believed that childhood is "another world" (Edwards, 1987), in some ways an ideal world - the dominant perception of childhood throughout the developed world for most of the 20th century. Early European criticism of the spiritual poverty of modern society developed in response to industrialization and urbanization lead to a romantic re-evaluation of pre-industrial society. Kinsella (1995) explains that, for the first time, past and more primitive lives in rural communities and in childhood were described as a period of innocence, simplicity, and spiritual unity that had been ruptured and destroyed by the corrupting and alienating forces of modern social relations and cities.

Urban nostalgia for this natural country life did not result in a cute aesthetic until this emotion was captured by Disney animation and communicated to mass audiences. Disney animations were acclaimed in Japan as much, if not more, than in America until they were banned for the period of the war. After the war going to see Disney films on specially designated days became a part of primary school education (Ono, 1983). Disney had a large influence on both Japanese animation and comics and in introducing the contemporary cute aesthetic into the country.

Contemporary cuteness is multifaceted; visual forms predominantly use largeeyed characters, bright colors and pastels, and biomorphic shapes. The history of the visual evolution of the original Mickey Mouse, from a rodent into the wellknown happy mouse follows a path of adding increasingly more cute features, such as a big head and eyes (Gould, 1979 ). However, while Disney cute was founded on a sentimental voyage back into an idealized country culture inhabited by joyful tiny animals and rural characters adopted from folk stories, Japanese cute became more focused on a sentimental voyage back into an idealized childhood (Ono, 1983). As Disney romanticized nature in relation to industrial society, Japanese cuteness romanticized childhood in relation to adulthood. By idolizing their childhoods and remnant childishness, young Japanese consumers implicitly ignored their individual futures as adults in society. Condemning adulthood was an individualized and limited way of condemning society in general.

There is no strong pattern of thought that links adulthood with individual emancipation in Japan (Kinsella, 1995). Western adulthood, linked to the authority and rights of the individual, is still thought of according to the Confucian model, in which maturity is normally regarded as the ability to cooperate well in a group, accept compromises, fulfill obligations to parents, employers, etc., and carry out social responsibilities. This underlying ideology is another reason why rebellion from society in Japanese youth culture has developed into a rebellion from adulthood as well (Kinsella, 1995). 


\section{Gender roles in cute}

As Martens (2008) points out, the aesthetic of "the cute" is an insufficiently examined phenomenon linking generational and gender imaginations with consumer culture in contemporary societies. It is clear that there could potentially be a huge consumer market for "the cute" that defies age and parental relations in the sense that people of different ages buy into it, in addition to those who are not parents. It is gendered in the sense that "the cute" appeals more to women and teenage girls than men, and connections may be identified between "the cute" and various feminine characteristics that link it with small, beautiful, feminine, and desirable. Historically, these associations are evident in the small shoe and foot treasured in Chinese culture and in Western fairy tales such as Cinderella (Martens et al., 2004).

Young women are the main generators of and actors in cute consumer culture. From the consumption of cute goods and services and the wearing of cute clothes, to the faking of childish behavior and innocent looks, young women are far more actively involved in cute culture than men. Japanese feminists charge that all this cute chic is really about the cultural domination and exploitation of women in the country (Bremner, 2006). It encourages girls and young women well into their late 20 s to act submissive, weak, and innocent rather than mature, assertive, and independent.

This is not to say that cuteness is not popular among Japanese young men. On the contrary, it is very popular, but young men are largely relegated to the passive, wistful, audiences of the performance of cute culture put on by women (Kinsella, 1995). Some boys are actively getting into the cute - or at least asexual-look. A recent trend is Japanese boys shaving their legs for the summer, short-pants season (Bremner, 2006).

The creation of cute consumer culture around young women has attracted some notice. While traditional mothers in the West complain that they can no longer tell apart the girls and boys because the girls all dress like boys these days, Japanese social commentators have bemoaned the domination of modern culture by young women and the increasingly cute, little girlish appearances of young men (Kinsella, 1995). Adolescent men do not represent freedom in the same way, and in their role as obedient company employees, neither do they exemplify any of the characteristics of the powerful, antagonistic, macho individualism of the male in Western societies and their youth cultures.

For many young men, cute culture represents freedom and an escape from the pressure of social expectations and regulations (Kinsella, 1995). Typically, these young men both wear cute fashions and emulate cute behavior themselves and fetishize young women depicted in Lolita complex comic books for adolescent boys, for example. Teenage Japanese girls (shôjo) provide the elusive model for cute culture. Shôjo, the leaders of cute, have been transformed into an abstract concept and a "sign" for consumption in the Japanese mass-media and modern intellectual discourse (for a detailed discussion, see Treat, 1993). 
While the "moratorium mentality" (Kinsella, 1995) and lack of desire to grow up and take on adult social roles and responsibilities was a feeling spread right through Japanese society in the 1980s, for women, the urge to prolong youth and its appearances took on the form of a profound struggle. Young women both savored their brief years of freedom as unattached urban socialites through decadent consumption and expressed their fears of losing their freedom and youth through the cute aesthetic. Shimamura (1991) notes that as young women get older, and particularly in the period immediately prior to marriage, their fascination with and immersion in cute culture becomes still more acute.

\section{Cute consumption}

In essays regarding the iconography of consumption, Harris (2000) focuses on the evolution of the symbols that define the culture of modern American consumption. The essays focus on the messages, or real meanings, behind such consumptionrelated communication vehicles as "cuteness," "the romantic," "deliciousness," "zaniness," "the natural," and "glamorousness." These icons and four others are the titles of the book's 10 essay chapters, each covering the verbal and visual cues that make up the modern message that has developed around each icon.

The first essay is on "cuteness." In it, Harris (2000) describes cuteness as evolving out of the human consumer's need to feel superior through pity for the "cute thing." He reinterprets items eliciting the, "awwww, isn't that cute," reaction as malformed, stunted, and robbed of any sort of power of their own. Thus, teddy bears have no teeth, claws, or even paws, and "Precious Moments" dolls have exaggerated eyes and bodies that are too small. Cute things are pitiful and call out to be befriended, or bought. Harris sees the cute as "exaggerating the vast discrepancies of power" (p.11). Thus, such "cute" activities as anthropomorphizing animals by dressing them in human clothes or even dressing children in adult-styled clothing is a way of emphasizing the inferior position of the pet or the child. Perhaps the argument that cute reinforces best our feelings of superiority is the trend towards the "anti-cute." Reality is harsh and getting harsher all the time, and that has brought about a backlash against the cute.

Young people enter cute consumer culture through consumption of cute goods with cute appearances and emotional qualities. The increasingly large disposable incomes of youth and young women (Granot et. al., 2010) and the inventiveness of marketers in providing goods to make them part with their money has a determining influence on the highly commercial nature of cute consumer culture. Cute seems to be accessible exclusively through consumption. This is both because it encourages hedonism and sensual pleasure necessitating consumption, and because even during youth and single days it was very difficult for female consumers to be cute full time. Cute culture, along with other youth cultures, could only be enjoyed during brief moments of private time such as at home between working and sleeping, or in the car, and in tiny private places such as inside handbags, presents, and pencil cases. There is not only no space for cute to become part of a "lifestyle," but 
the fantastical nature of cute culture itself contains so few references to real life and society that there is in any case little way of understanding it in terms of everyday life. Cute culture has to be entered and left in a matter of minutes or moments that lends it to construction by ephemeral products and places of consumption of goods and leisure services (Kinsella, 1995). Based on this, we feel that consumption of cute goods provides an escape for the consumers of cute.

Unlike even those ironically well-marketed Western origin youth cultures, such as punk and grunge, cute consumer culture does not condemn materialism and the display of wealth. Many contemporary Western youth cultures have been distinctly opposed to, among other things, modern consumer culture (Belk et al., 2008), encouraging a tendency for hip youth to condemn materialism, appear to or actually buy little, dress down, and find cheap, secondhand goods with which to adorn themselves. To the contrary, personal consumption is portrayed as something rather anti-social and immoral in mainstream Japanese society and cute youth culture goes against the grain of older social values by sanctioning consumption.

\section{Cute and (Western) consumer culture theory}

As Martens (2008) explains, there are indications that "the cute" is a more universally appreciated aesthetic in Japanese society (Tosca, 2003), but in "the West" the cultural significance of "the cute" is symptomatic, for instance, in the cute animal and child imagery used extensively in the card and poster industry (Higonnet, 1998). As stated earlier, consumers have difficulties putting into words what makes something cute and why they like it, but "the cute" is visually easily identifiable and clearly generates a sense of desire and emotional affect in certain people.

As Arnould and Thompson (2005) suggest, rather than viewing culture as a rather one-dimensional structure of joint meanings, lifestyles, and values shared by a member of society (e.g., Americans share this kind of culture; Japanese share that kind of culture), CCT "explores the heterogeneous distribution of meanings and the multiplicity of overlapping cultural groupings that exist within the broader socio-historic frame of globalization and market capitalism" (p.129).We agree that consumer culture denotes a social arrangement in which the relations between lived culture and social resources, and between meaningful ways of life and the symbolic and material resources on which they depend, are mediated through markets. The consumption of market-made commodities and desire-inducing marketing symbols, which is inherent to cute culture, is also central to consumer culture, and yet the perpetuation and reproduction of this system is largely dependent upon the exercise of free personal choice in the private sphere of everyday life (Holt, 2002).

The term "consumer culture" conceptualizes an interconnected system of commercially produced images, texts, and objects that groups use - through the construction of overlapping and even conflicting practices, identities, and meanings - to make collective sense of their environments and to orient their 
members' experiences and lives (Kozinets, 2001). These meanings are embodied and negotiated by consumers in particular social situations, roles, and relationships.

Further, consumer culture describes a densely woven network of global connections and extensions through which local cultures are increasingly interpenetrated by the forces of transnational capital and the global mediascape (Appadurai, 1990; Slater, 1997; Wilk, 1995). In a similar manner to the way cool began its trajectory from being a defensive mechanism of black jazz musicians, to becoming the attitude of choice of youth everywhere (Nancarrow et al., 2002), cute has evolved from its Asian-Pacific origins to a global consumer culture.

Probably the first hints that Western consumer culture, led by American consumers, was about to embark on a veritable odyssey of cute came from the ravers and club kids of the 1980s, whose fashions and music were themselves inspired by a combination of 1960s hippie bliss and 1970s disco frenzy (Newitz, 2002a). Raverfriendly happy faces, day-glo accessories, psychedelic patterns, and unique, plushy sneakers began to find their way into urban boutiques, and later into suburban malls.

The cuteness of rave culture had its counterpoint in the burgeoning Web industry of the mid 1990s. Basic, bright, cartoon-like images filled the Web as it evolved into a dominant mass medium. Wired magazine took its cues from early digital design, playing with neon colors and exaggeratedly low-resolution graphics; later, Webzines such as Suck and Word were famous for their random cartoon-like images, which set the tone for dozens of other Web culture sites (Newitz, 2002a). Cuteness was the aesthetic of early Web sites, and digital cuteness influenced graphic design generally. As described earlier, cuteness also owes much to Asian pop culture - especially from Japan. Although Japan's Godzilla, Hello Kitty, and Robotech had been staples in America for decades, the 1990s saw an unprecedented escalation in the availability of Japanese anime (cartoons), manga (comic books), fashions, movies, and ideas in the United States. By the end of the 1990s, nothing was more popular than Asian pop. Moreover, nothing was cuter.

Newitz (2002a) claims consumers live in a "cuteocracy," where the cutest person, place, or thing wins. Retail outlets offer cute items, and consumers are looking for "cute, old-fashioned clothes that are girly and pretty" (p.12). Customers "grew up with Disney and other iconic figures, so there's something calming and fun about putting that kind of cuteness into everyday fashion" (p.14). In a 2012 article, Sanchez discusses the effects of what is termed the "princess culture." Little girls dress in princess attire, at the time they are building their self-esteem. Some are concerned that by doing this, little girls are getting the message that "being nice and pretty are the most important thing to being a girl. Not being smart assertive, or strong." The article also goes on to say these products at an early age push girls to focus on their looks and when these girls overly focus on their appearance, they may encounter things such as distorted body images, eating disorders, or poor sexual choices. 
Many of the cute images and icons came from idealistic, hopeful social and cultural movements of the 1960s and the exuberant subcultures of early-1990s clubbers and digital dreamers. Contemporary cuteness has lost some of the subversive edge it had back in the days when raves and manga in the United States were still mostly the purview of underground culture enthusiasts. Modern-day cute is a consumer culture phenomenon, a mainstream aesthetic. Stores such as Victoria's Secret (especially its PINK line) and Urban Outfitters, which cater to the cute consumers, do not normally carry women's sizes that go above an eight. Cuteness also glamorizes babyish, mindless behavior in women. Moss (2001) discusses Hello Kitty, a cute icon who is in the third grade, which is about the age bracket in which a cute girl is supposed to exist, perpetually cooing over dollies, stickers, and boys, never growing up and becoming a competent, independent adult (Newitz, 2002a).

The marketing of cuteness involves a degree of "cultural amnesia" (Jenkins et al., 2002) in which an entire society forgets about its problems by consuming mass media. Cultural amnesia, according to Rogin, is about using appealing images to erase or modify memories of painful historical and political realities. Looked at from this perspective, cuteness is a kind of cultural decoy, a soothing and simple distraction from a world whose boundaries and problems are becoming more complex by the day.

Maynard and Taylor (1999) address cross-cultural variability in the manner in which marketers portray teenage girls. Specifically, the level to which "girlish" images are portrayed in Japan and the United States by employing a content analysis of advertisements appearing in issues of magazines geared toward teenage girls. They discuss culture-based differences in advertising with a specific focus on how advertising constructs the image of teenage girls, and how, in turn, teenage girls are encouraged to identify with their mediated images of self. As noted by Pollay (1986), advertising works within a cultural context, selectively reinforcing the styles, roles, and values of the culture.

\section{Discussion}

Cute gives consumer goods warm and cheerful qualities. After the production process had de-personalized goods, cute design attempts to re-personalize it. Consumption of cute goods with powerful emotion-inducing properties could ironically disguise and compensate for the very isolation of individuals in contemporary society. Cuteness loans personality and a subjective presence to otherwise meaningless - and often literally useless - consumer goods, and in this way makes them much more attractive to consumers. The product could appear to have a character of its own because of its winsome mammalian shape, for example little round, weeping digitalized vacuum cleaners and rice cookers, or the 1980s' mini caasu (little cars) designed to feel playful and cuddly. Modern consumers might not be able to meet and develop full relationships with people, but the 
implication of cute design was that they could always attempt to develop them with cute objects (Kinsella, 1995).

CCT research emphasizes the productive aspect of consumption (Arnould and Thompson, 2005). It explores how consumers actively rework and transform symbolic meanings encoded in advertisements, brands, retail settings, or material goods to manifest their particular personal and social circumstances and further their identity and lifestyle goals (Grayson and Martinec, 2004; Holt, 2002; Kozinets, 2001, 2002; Mick and Buhl, 1992; Penaloza, 2000, 2001; Ritson and Elliott, 1999; Scott, 1994). From this perspective, the marketplace provides consumers with an expansive and heterogeneous palette of resources from which to construct individual and collective identities (e.g., Murray, 2002; Schau and Gilly, 2003; Thompson and Hirschman, 1995). Grounded in CCT, this paper serves as an initial attempt to explore the concept of cute, the role of female consumers as cultural intermediaries, and how marketing might influence this process.

It can be reasonably argued that an understanding of the concept of cute is important to a balanced understanding of subjectivity in contemporary consumer culture, not only in youth markets but also in older lifestyle markets. The connection between cute and sexy that brands such as Victoria's Secret have capitalized on, allows modern women to maintain an external appearance of their choice while remaining girlishly cute and sometimes sexy inconspicuously. Victoria's Secret markets its undergarments as sexy; one of our participants states that they usually purchase underwear from Victoria's Secret as long as it is cute.

We find that cute has ascended from being an Asian, Japanese consumer culture to a world-wide consumer cultural phenomenon. Hello Kitty is anything but inconspicuous. Consumer brands such as Mini, Motorola, Volkswagen, and others have embraced cute as a design aesthetic. Advertisers also borrow cute to lend its status to their brands. This too suggests that cute, with Japan being the key source of global cute due to global media, has transformed from local to global; from kitschy to desirable; from mindless childishness to longing for eternal youth.

\section{Future research and marketing implications}

The present study offers several opportunities for further investigation of cute, as well as an extension into cute advertising. As we stated earlier, the concept of cool has been substantially researched in academic literature, but there has been no significant research to understand the concept of cute. In terms of future research it would be interesting to include observation in situ and classical socio-metric analysis of cute consumption as a means both to validate the theoretical discussion provided in this paper and potentially to provide further insights. Our main focus has been cute in the Japanese culture and we also touched on Western culture.

In more practical terms, this research identified the kind of cultures and subcultures that consumers participate in and, thus, a focus for marketing activities. For example, Kinsella (1995) states that cute culture was not founded in business but by youth culture amongst Japanese, specifically young women. Marketing the cute 
aspect of youth culture has been a lucrative business. Without an understanding of how the process of designating something as cute works and the importance of cultural intermediaries in this designation, a key element underpinning the cultural construction of consumption will remain under-explored.

\section{Funding}

This research received no specific grant from any funding agency in the public, commercial or not-for-profit sectors.

\section{References}

Allison A (2003) Portable monsters and commodity cuteness: Pokémon as Japan's new global power. Postcolonial Studies 6(3): 381-398.

Angier N (2006) The cute factor. The New York Times (3 January 2006).

Appadurai A (1990) Disjuncture and Difference in the Global Cultural Economy, Theory, Culture, Society. London: Sage, pp. 295-310.

Arnould EJ and Thompson CJ (2005) Consumer culture theory (CCT): Twenty years of research. Journal of Consumer Research 31(4): 868-882.

Beggan JK and Allison S (2001) The Playboy rabbit is soft, furry, and cute: Is this really the symbol of masculine dominance of women? Journal of Men's Studies 9(3): 341-370.

Belk RW, Tian K and, Paavola H (2008) Consuming cool: Behind the unemotional mask. Research in Consumer Behavior (12): 183-208.

Bourdieu P and Nice R (1984) Distinction: A Social Critique of Judgment of Taste. London: Routledge.

Brake M (1985) Comparative Youth Culture: The Sociology of Youth Culture and Subcultures in America, Britain and Canada. New York: Routledge.

Bremner B (2002) In Japan, cute conquers all. (Summer 2002) Available at: http://www. businessweek.com/stories/2002-06-24/in-japan-cute-conquers-all (accessed 14 July 2012).

Brooks D (2000) BOBOs in Paradise: The New Upper Class and How They Got There. New York: Simon and Schuster.

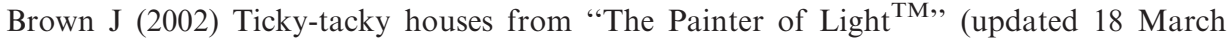
2002). Available at: http://archive.salon.com/mwt/style/2002/03/18/kinkade_village/ (accessed 11 January 2008)

Butler J (1990) Gender Trouble. London: Routledge.

Cross G (2002) Valves of desire: A historian's perspective on parents, children, and marketing. Journal of Consumer Research 29(3): 441-447.

Cross G (2004a) The Cute and the Cool: Wondrous Innocence and Modern American Children's Culture. New York: Oxford University Press.

Cross G (2004b) Wondrous innocence. Printing advertising and the origins of permissive child rearing in the US. Journal of Consumer Culture 4(2): 183-201.

Edwards W (1987) The commercialised wedding as ritual. Journal of Japanese Studies 13(1): 51-78.

Garger I (2007) Hello Kitty: One nation under cute. Psychology Today. 
Goffman E (1979) Gender Advertisements. New York, NY Harper and Row; London: Macmillan.

Gould SJ (1979) A Biological Homage to Mickey Mouse, The Panda's Thumb, W.W. Norton \& Company, 1980 .

Granot E, Greene H and Brashear TG (2010) Female consumers: Decision-making in brand-driven retail. Journal of Business Research 63(8): 801-808.

Grayson K and Martinec R (2004) Consumer perceptions of iconicity and indexicality and their influence on assessments of authentic market offerings. Journal of Consumer Research 31(1): 296-313.

Harris D (2000) Cute, Quaint, Hungry and Romantic: The Aesthetics of Consumerism, 1st edn. New York: Basic Books.

Higonnet A (1998) Pictures of Innocence: The History and Crisis of Ideal Childhood. New York: Thames and Hudson.

Hjorth L (2005) Odors of mobility: Mobile phones and Japanese cute culture in the AsiaPacific. Journal of Intercultural Studies 26(1): 39-55.

Holt DB (2002) Why do brands cause trouble? A dialectical theory of consumer culture and branding. Journal of Consumer Research 29(1): 70-90.

Huyssen A (1986) After the Great Divide: Modernism, Mass Culture \& Postmodernism. London: Macmillan.

Innes SA (1999) Tough Girls: Women, Warriors, and Wonder Women in Popular Culture. Philadelphia, PA: University of Pennsylvania Press.

Jenkins H, McPherson T and Shattuc J (2002) Hop on Pop: The Politics and Pleasures of Popular Culture. Durham, NC, Duke University Press.

Kato M (2002) The Japanese obsession with adorable icons is rooted in cultural tradition. (Summer 2002) Available at: http://www.eyemagazine.com/feature/article/cute-culture (accessed 14 July 2012).

Kinsella S (1995) "Cuties in Japan" in Women, media and consumption in Japan. Skov L and Moeran B (eds.), Honolulu, Hawaii, University of Hawaii Press.

Ko Y (2003) "Consuming differences: "Hello Kitty" and the identity crisis in Taiwan. Postcolonial Studies 6(2): 175-189.

Kozinets RV (2001) Utopian enterprise: Articulating the meaning of Star Trek's culture of consumption. Journal of Consumer Research 28(1): 67-89.

Kozinets RV (2002) Can consumers escape the market? Emancipatory illuminations from burning man. Journal of Consumer Research 29(1): 20-38.

Langmeyer L and Shank M (1994) Managing beauty - Products and people. Journal of Product \& Brand Management 3(3): 27-38.

Lee D (2005) Inside look at Japanese cute culture (1 September 2005). Available at: http:// uniorb.com/ATREND/Japanwatch/cute.htm (accessed 11 January 2008).

Ling R (2004) The Mobile Connection. San Francisco, CA: Morgan Kaufmann Publishers.

Martens L (2008) The Cute, the Spectacle and the Practical: Narratives of New Parents and Babies at the Baby Show, [Leaflet] Keele University.

Martens L, Southerton D and Scott S (2004) Bringing children (and parents) into the sociology of consumption: Towards a theoretical and empirical agenda. Journal of Consumer Culture 4(2): 155-182.

Martin DM, Schouten JW and McAlexander JH (2006) Claiming the throttle: Multiple femininities in a hyper-masculine subculture. Consumption, Markets and Culture 9(3): 171-205. 
Maynard ML and Taylor CR (1999) Girlish images across cultures: Analyzing Japanese versus U.S. Seventeen Magazine ads. Journal of Advertising 28(1): 39-48.

McRobbie A (1991) Feminism and Youth Culture. London: Macmillan, pp. 81-82.

McVeigh BJ (2000) How Hello Kitty commodifies the cute, cool and camp: "Consumutopia" versus "Control" in Japan. Journal of Material Culture 5(2): 291-312.

McVeigh BJ (2003) Individualization, Individuality, Interiority, and the Internet, Japanese Cybercultures. London: Routledge, pp. 19-33.

Mick DG and Buhl C (1992) A meaning-based model of advertising experiences. Journal of Consumer Research 19(1): 317-338.

Moon Y (2000) Intimate exchanges: Using computers to elicit self-disclosure from consumers. Journal of Consumer Research 26(4): 323-339.

Moss M (2001) Hello Kitty, hello everything: 25 years of fun. New York, NY Harry N. Abrams, Inc.

Murray JB (2002) The politics of consumption: A re-inquiry on Thompson and Haytko's (1997) 'Speaking of Fashion'. Journal of Consumer Research 29(1): 427-440.

Nancarrow C, Nancarrow P and Page J (2002) An analysis of the concept of cool and its marketing implications. Journal of Consumer Behavior 1(4): 311-322.

Newitz A (2002a) The apotheosis of cute: How fluffy bunnies, bouncy kittens, and the Clinton era brought cuteness to an awful climax (1 January 2002). Available at: http:// www.sfbg.com/36/17/news_cute.html .

Newitz A (2002b) Why is everything so damn cute? The fluffy-bunny regime is getting ugly. San Francisco Bay Guardian 38(17): 20-21.

Nye Jr JS (2006) Transformational leadership and U.S. grand strategy. Foreign Affairs 85(4): $139-148$.

Ono K (1983) Disney and the Japanese. Look Japan 10(7): 6-12.

Penaloza L (2000) The commodification of the American West: Marketers' production of cultural meanings at a trade show. Journal of Marketing 64(1): 82-109.

Penaloza L (2001) Consuming the American West: Animating cultural meaning at a stock show and rodeo. Journal of Consumer Research 28(1): 369-398.

Pollay R (1986) The distorted mirror: Reflections on the unintended consequences of advertising. Journal of Marketing 60(1): 18-36.

Ritson M and Elliott R (1999) The Social Uses of Advertising: An Ethnographic Study of Adolescent Advertising Audiences. Journal Of Consumer Research 26(3): 260-277.

Robinson-English T (2006) Saving black boys. Is single-sex education the answer? Ebony Magazine, p.52. (1 December 2006).

Roux D and Korchia M (2006) Am I what I wear? An exploratory study of symbolic meanings associated with secondhand clothing. Advances in Consumer Research 33(1): 29-35.

Ruth JA, Otnes CC and Brunel FF (1999) Gift receipt and the reformulation of interpersonal relationships. Journal of Consumer Research 25(4): 385-402.

Sanchez K (2012) Expert argues the princess culture is not a fairy tale (23 February 2012). Available at: http://www.nbcbayarea.com/news/local/Expert-Argues-Princess-CultureIs-Not-a-Fairy-Tale-140165973.html (accessed 16 September 2012).

Schau HJ and Gilly MC (2003) We are what we post? Self-presentation in personal web space. Journal of Consumer Research 30(1): 385-404.

Schroeder JE (2006) Aesthetics awry: The Painter of Light ${ }^{\mathrm{TM}}$ and the commodification of artistic values. Consumption, Markets \& Culture 9(2): 87-99.

Scott LM (1994) The bridge from text to mind: Adapting reader- response theory to consumer research. Journal of Consumer Research 21(1): 461-480. 
Shelton JA and Okleshen Peters C (2006) Actions speak as loud as products: Disposition as a self-perceptive method of identity incorporation. Consumption, Markets and Culture 9(3): 207-233.

Shimamura M (1991) Fancy Research: How Cute Controls People, Objects and Money. Tokyo: Nesco.

Slater D (1997) Consumer Culture and Modernity. London: Polity.

Stokes DL (2007) Things we like: Human preferences among similar organisms and implications for conservation. Human Ecology 35(1): 361-369.

Sugawa K (2000) Change in premiership and Japan's soft power. The Asahi Shimbun, (25 April 2000).

Thompson CJ and Hirschman EC (1995) Understanding the socialized body: A poststructuralist analysis of consumers' self-conceptions, body images, and self-care practices. Journal of Consumer Research 22(1): 139-153.

Thompson CJ, Locander WB and Pollio HR (1990) The lived meaning of free choice: An existential-phenomenological description of everyday consumer experiences of contemporary married women. Journal of Consumer Research 17(3): 346-361.

Thornton S (1995) Club Cultures: Music, Media and Subcultural Capital. Cambridge: Polity.

Tosca SP (2003) The appeal of cute monkeys. In: proceedings of level up digital games researchers association conference, Utrecht, the Netherlands, November 2003.

Treat J (1993) Yoshimoto Banana writes home: Shôjo culture and the nostalgic subject. Journal of Japanese Studies 19(2): 353-387.

Wallendorf M and Arnould EJ (1991) "We gather together": Consumption rituals of Thanksgiving Day. Journal of Consumer Research 18(1): 13-31.

Wilk R (1995) Learning to Be Local in Belize: Global Systems of Common Difference, Worlds Apart: Modernity through the Prism of the Local. London: Routledge, pp. 110-131.

Williams R (1965) The Long Revolution. Harmondsworth: Penguin.

Wilson T, Huey Pyng T and May L (2006) Television's glocal advertising in veridical product narrative: A SE Asian reception study of consumer alignment/alienation. Consumption, Markets \& Culture 9(1): 45-62.

Post-print standardized by MSL Academic Endeavors, the imprint of the Michael Schwartz Library at Cleveland State University, 2016 